\title{
Sastra Warna Lokal dan Multikulturalime di Indonesia
}

\author{
Atmazaki \\ Universitas Negeri Padang \\ atmazaki@fbs.unp.ac.id
}

\begin{abstract}
Abstrak
Makalah ini membahasa karakteristik sastra warna lokal dalam konteks masyarakat multikultural di Indonesaia. Di tengah perubahan masyarakat yang semakin cepat sehingga multikultalisme menjadi sesuatu yang tidak bisa dihindari, sastra dapat digunakan sebagai wahana untuk memahami kondisi itu. Dalam konteks pemertahanan kesatuan dan masuk ke dunia global itulah, ide-ide multikulturalisme perlu mendapat tempat di dalam pendidikan, terutama pendidikan dasar dan menengah. Salah satu sarana untuk mengembangkan ide-ide multikulturalisme itu adalah pendidikan apresiasi sastra dengan memanfaatkan karya-karya sastra warna lokal yang sangat kaya di Indonesia. Pemabahasan mencakup karakteristik sastra warna lokal, konsep-konsep multikultural, dan jender yang relevan dengan keadaan Indonesia. Kemudian, dikemukan konsep/pemikiran untuk memanfaatkan sastra warna lokal untuk dijadikan bahasan dalam pendidikan multikultral yang berperspektif jender dalam konteks Indonesia yang multietnik, multiagama, multibahasa, dan multikultural.
\end{abstract}

Kata kunci: sastra warna lokal; masyarakat multikultural; kesetaraan jender

\section{Pendahuluan}

Negara Indonesia terdiri atas berbagai suku dengan perbedaan bahasa, budaya, adat istiadat, dan agama dan kepercayaan. Apabila masing-masing suku itu menganggap karakteristik mereka perlu dipertahankan karena dianggap penting demi kelangsungan hidup mereka maka hal itu merupakan sesuatu yang wajar. Apabila masing-masing tidak menganggapnya demikian, berarti suku tersebut merasa sebagai kelompok inferior dalam negara kesatuan Indonesia. Namun demikian, pandangan etnisentrisiti itu tidak berarti bahwa suatu kelompok etnis boleh melecehkan/menganggap rendah suku yang lain karena pandangan seperti itu bermuatan konflik. Apabila hal itu terjadi, negara kesatuan Indonesia yang selalu dipertahankan ini bisa bubar dan perpecahan akan segara menunggu.

Kesadaran akan perlunya kesatuan, sebenarnya, sudah berkembang pada masyarakat Indonesia. Tidak saja karena telah ditetapkannya bentuk negara kesatuan dalam hasil amandemen UUD 45 tahun 2003, tetapi juga munculnya kesadaran HAM, jender, dan maraknya wacana tentang multikulturaisme dalam dialog-dialog ilmiah. Hal itu suatu pertanda baik bahwa bangsa Indonesia memang masih ingin mempertahankan persatuan dalam kemajemukan. Namun, apabila semangat itu tidak diiringi dengan 
upaya-upaya nyata, impian untuk tetap berada dalam negara kesatuan akan mudah tergerogoti oleh pandangan etnisentrisiti sempit.

Sudah merupakan hukum waktu bahwa dunia kita berubah secara cepat. Perubahan itu tidak saja mengakibatkan munculnya pandangan yang berbeda tentang dunia tetapi juga dalam bahasa untuk menamai dunia baru itu (globalisasi, negara bangsa, masyarakat madani, dsb). Kata-kata lama mengambil makna baru dan kata-kata baru masuk ke dalam kosa kata wacana hari ini yang mengakibatkan cara yang berbeda dalam "memandang" sesuatu. (Rosado, 1996)

Dalam rentangan waktu yang tidak begitu lama, situasi dunia telah bepindah/berubah dari masyarakat agraris yang konformitas ke masyarakat industri yang nasionalis dan uniformitas, terus ke masyarakat informasi dalam konteks global, dan sekarang mulai masuk ke situasi masyarakat global yang planetari (Wilson, 2004). Perubahan masyarakat yang demikian membawa konsekuensi masing-masing pada hubungan antarindividu dan antarmasyarakat yang mempunyai keunikan budaya masing-masing. Pada masyarakat dunia ketiga, globalisasi datang melalui pemaksaan karena secara budaya belum siap menerimanya, tetapi bagi negara-negara maju, globalisasi berlangsung secara inklusif karena datangnya memang dari proses kemajuan yang mereka alami. Dalam konteks Indonesia, globalisasi yang dipaksakan itu sering membawa dampak yang kurang pas. Dunia pariwisata, misalnya, mengubah corak kehidupan masyarakat dalam berbagai aspek kehidupan baik ekonomi, sosialbudaya, maupun ideologi. Generasi muda tiba-tiba ingin meninggalkan pertanian dan berbondong-bondong ke kota. Sepulang dari kota, "kehidupan di desa" mereka protes karena dianggap tidak sesuai dengan kemajuan. Akan tetapi, karena kedodoran dalam memandang kemajuan, maka generasi tua melihatnya sebagai "kelepasan". Oleh karena tak mungkin kembali ke dalam tatanan lama yang agraris, satu persatu tradisi dilepaskan, dan satu persatu modernitas diambil dengan prasangka-prasangka.

Dalam konteks pemertahanan kesatuan dan masuk ke dunia global itulah, ideide multikulturalisme perlu mendapat tempat di dalam pendidikan, terutama pendidikan dasar dan menengah. Salah satu sarana untuk mengembangkan ide-ide multikulturalisme itu adalah pendidikan apresiasi sastra dengan memanfaatkan karyakarya sastra warna lokal yang sangat kaya di Indonesia.

Artkel ini bertujuan untuk menjelaskan karakteristik sastra warna lokal, konsepkonsep multikultural, dan jender yang relevan dengan keadaan Indonesia. Kemudian, dikemukan konsep/pemikiran untuk memanfaatkan sastra warna lokal untuk dijadikan bahasan dalam pendidikan multikultral yang berperspektif jender dalam konteks Indonesia yang multietnik, multiagama, multibahasa, dan multikultural 


\section{Pembahasan}

\section{Sastra Warna Lokal}

Sastra berlatar belakang daerah, berupa adat istiadat, kebiasaan-kebiasaan, dialek, cara berpikir dan berperasaan masyarakat disebut sebagai sastra warna lokal (Abrams, 1971:89). Hal yang penting dalam kaitan warna lokal adalah kehidupan sosial dan alam pikiran yang hanya mungkin ada secara setempat (lokalitas), tidak sekadar tempat secara fisik (Navis, 1999:177).

Dalam konteks Indonesia, sastra warna lokal bukanlah sastra daerah, tetapi sastra Indonesia berlatar belakang daerah, baik novel dan drama maupun puisi. Sudah barang tentu, setiap sastra warna lokal akan mecitrakan sikap-sikap, cita-cita, identitasidentitas masyarakat setempat. Semua itu akan berpengaruh dalam memandang, baik tentang diri sendiri maupun orang lain yang berbeda kelokalannya.

\section{Multikulturalisme}

Multikulturalisme adalah suatu sistem tingkah laku yang memahami dan menghormati keberagaman kelompok; mengakui dan menghargai perbedaan sosiokultural; mendrong dan memungkinkan kontribusi secara terus menerus dalam suatu konteks kultur inklusif dalam suatu organisasi atau masyarakat (Rosado, 1996). Sebagai suatu sistem, multikulturalisme menghiasi keseluruhan pengalaman keseharian manusia dalam komunitasnya yang beragam. Ke dalamnya tercakup cacara-cara manusia memandang orang lain, paradigma dasar mereka, dan bagaimana ini semua berdampak terhadap orang lain dan terhadap perilaku sendiri.

Multikulturalisme menghendaki pengakuan terhadap validitas ekspresi dan kontribusi kultural yang diberikan oleh kelompok masyarakat yang berbeda. Ini tidak berimplikasi bahwa semua kontribusi kultural dinilai sama dan semua masyarakat dinilai sama, atau bahwa semua harus ditoleransi secara sama. Beberapa praktek kultur tertentu dapat lebih baik daripada yang lain bagi kemajuan masyarakat. Multikultural juga medorong dan memungkinkan kontribusi kelompok masyarakat atau organisasi yang berbeda. Perempuan dan orang berkulit hitam, misalnya, sering tidak mendapat dorongan untuk maju karena apa yang mereka bawa sering dipandang kecil dan kurang bernilai. Sikap-sikap seperti ini bukanlah bagian dari ide-ide multikultural.

Multikulturalisme juga merupakan kemampuan untuk berbagi kebanggaan dengan orang lain dengan meminimalisasi rintangan-rintangan. Paham ini memungkinkan kita untuk melihat orang lain tanpa curiga. Masing-masing tidak menganggap yang satu sebagai "predator" bagi yang lain, tetapi sebagai partner yang saling menguntungkan. Multikulturalisme juga bersifat inklusif, yaitu sistem yang tidak melihat individu dan masyarakat secara gabungan antarbudaya tetapi sebagai suatu kesatuan yang beragam (melihatnya sebagai sesuatu yang berwarna-warni, bukan warna-warni yang bersatu). 
Kelima konsep dasar multikulturalisme itu memungkinkan timbulnya suatu fermentasi perubahan yang dapat memunculkan "iklim baru" dalam kemajemukan kultural yang perlu diletakkan di atas struktur "iklim lama".

Menurut Feinberg (1996), pluralisme dan multikulturalisme datang dari sumber yang sama, yaitu teori politik dan pendidikan liberal, tetapi keduanya mempunyai arah dan representasi yang berbeda. Pluralisme menganggap bahwa suatu masyarakat yang di dalamnya terdapat orang-orang dari kultur dan orientasi yang berbeda boleh-boleh saja mengekpsresikan pandangan hidupnya masing-masing secara terpisah. Pluralisme menginginkan persamaan kesempatan dalam lingkungan yang bebas; tidak merasa perlu menghancurkan memori masa lalunya atau menghapuskan keberagaman budayanya. Bagi penganut paham pluralis, masyarakat tidak mempunyai tanggung jawab khusus untuk memelihara atau mendukung struktur budaya secara keseluruhan. Yang mesti dipelihara adalah kondisi individu yang memunyai kemungkinan-kemungkinan pilihan. Multikulturalisme menghargai perbedaan dan keaslian budaya dan menganggap perlu untuk memeliharanya tanpa semata-mata bergantung pada interes individu atau kelompok budaya. Masing-masing kekuatan budaya perlu dijaga untuk dimanfaatkan sebagai penopang kekuatan bersama. Bagi penganut multikulturalisme, keragaman budaya adalah kekayaan yang harus dijaga bersama-sama, bukan tanggung jawab pemilik kultur itu saja.

Selanjutnya, Feinberg (1996), menjelaskan bahwa pluralisme menganggap publik sudah memunyai kultur masing-masing; institusinya dibentuk oleh tradisi-tradisi kelompok yang sama dan tidak yang lain; keuntungan pendidikan dan pekerjaan didistribusikan secara tidak seimbang/tidak sama menurut faktor etnis, ras, dan kelas sosial. Multikulturalisme juga menganggap publik sudah memunyai kultur masingmasing, tetapi institusi dibentuk berdasarkan persamaan antarkelompok. Mereka tidak memelihara "dinding pemisah" antara kultur dan publik, tetapi memastikan bahwa tidak ada kelompok yang mendominasi lingkungan publik tertentu. Lingkungan publik dilihat sebagai arena negosiasi kultural yang tujuannya adalah inklusi, budaya, dan sebagainya. Publik lebih terlihat sebagai "bazar" terbuka ketimbang ruang pengadilan.

Pluralisme membiarkan identitas kultural untuk tumbuh, sedangkan multikulturalisme medorongnya untuk tumbuh. Pluralis menganut secara dominan prinsip asosiasi bebas dan kesempatan yang sama, sedangkan multiklturalis menganut prinsip afiliasi dan pemahaman budaya. Multikuluralis menghendaki pandanganpandangan individu sebagai bagian dari kolektivitas yang memberikan makna bagi hidup mereka dan dilihat sebagai cara untuk mendukung kolektivitas.

Dari pengertian dan karakteristik multikultural itu dapat dipahami bahwa konsep ini sangat penting diadopsi untuk konteks Indonesia. Bangsa Indonesia tidak cukup hanya membiarkan perbedaan etnis, agama, bahasa, dan budaya berkembang sendiri tapa adanya kesadaran multikulralisme itu. Setiap suku harus menghormati suku lain dalam segala perbedaan yang ada pada masing-masingnya. Keadaran multikulturalisme sulit tumbuh dengan sendirinya apabila tidak disosialisasikan kepada generasi penerus. 


\section{Jender}

Sosiolog telah membuat suatu pembedaan yang penting antara seks dan jender. "Seks" mengacu pada perbedaan biologis antara laki-laki (male) dan perempuan (female), sedangkan "jender" mengacu pada kepribadian yang ditentukan secara sosial dan ciri-ciri psikologis yang diasosiasikan sebagai laki-laki (masculinity) atau perempuan (feminity). Seks dan jender jelas terkait meskipun hakikatnya yang pasti selalu menjadi perdebatan di kalangan sosiolog, feminis, dan ahli-ahli lain (Garret, 1992:vii). Perbedaan seks secara biologi ini telah digunakan untuk menjelaskan dan melegitimasi pembagian kerja secara seksual baik dalam keluarga maupun dalam masyarakat (Garret, 1992: 3-5).

Menurut Kelly L. Rose (2003)Tabel oposisi yang dibuat Pythagoras menunjukkan bahwa sejak zaman Yunani Kuno telah terjadi ketidakseimbangan jender dengan menempatkan perempuan (female) pada kolom yang sejajar dengan: unlimited, even, plurality, left, moving, curved, darkness, bad, and oblong; sedangkan laki-laki (male) disejajarkan dengan limited, odd, one, right, resting, straight, light, good, and square. Kesejajaran oposisi ini, di Cina, mirip dengan konsep Yin: even, female, and darkness; konsep Yang: odd, male, and light. Di India juga terdapat oposisi yang hampir sama. Di samping Tuhan Shiva, laki-laki dianggap detached (superior), remote, and unmoving; sedangkan perempuan dianggap active, creative, and powerfull.

Sebagai seorang feminis, Rose menganggap teori Jung tentang arketipe seksual adalah seksis: laki-laki identik dengan logos (rasional); perempuan disamakan dengan eros (emosional). Bagaimanapun, menurut Rose, kedua fungsi ini ada dalam pikiran laki-laki dan perempuan, yang membedakannya adalah kedinamisannya. Laki-laki cenderung mempunyai sentimen irasional, sedangkan perempuan cenderung mempunyai opini irasional. Rose juga mengeritik pendapat Deborah Tannen yang mengatakan bahwa laki-laki menggunakan percakapan untuk menjaga status atau untuk informasi; perempuan menggunakan percakapan untuk menjaga kedekatan (closeness). Menurut Rose, hal ini sama dengan fungsi logos dan eros karena informasi adalah rasional, sedangkan kedekatan adalah emosional. Laki-laki boleh jadi melihat kedekatan dalam arti status; perempuan melihat status dalam arti kedekatan. Ada hubungan antara stereotipe jender dengan arketipe seksual. Perbedaan bentuk organ seksual perempuan dan laki-laki menimbulkan pebedaan stereotipe sehingga perempuan disebut dark, hiden, and internal; sedangkan laki-laki disebut light, closer, and external.

Keseimbangan jender merupakan konsep yang sangat sering dibahas, tetapi sangat sulit diterapkan karena masyarakat sudah terlanjur begitu lama berada dalam pemikiran dan perasaan bahwa laki-laki lebih unggul dalam segala hal daripada perempuan. Pandangan bias jender ini perlu diluruskan agar terdapat keseimbangan peran antara laki-laki dan perempuan.

\section{Pendidikan Multikultural}

Pada dasarnya, pendidikan multikultural merupakan pengenalan-pengenalan berbagai budaya kepada murid-murid, bukan untuk mempertentangkannya tetapi untuk 
memahami persamaan-persamaannya. Lebih khusus, tujuan pendidikan multikultural adalah untuk mengembangkan pemahaman tentang keberagaman budaya kelompok etnis, warisan etnik sebagai faktor gaya hidup, dan sejarah kelompok etnis.

Di samping itu, pendidikan multikultural bertujuan mengembangkan keterampilan yang diperlukan untuk berpartisipasi dalam kelompok etnis yang berbeda; berkomunikasi dengan kelompok minoritas dan mayoritas; menyelesaikan konflik dan melakukan aksi untuk mengatasi masalah sesuai dengan kondisi setempat; mengembangkan sikap, nilai, dan perilaku yang mendukung keberagaman budaya dan perbedaan etnis; melawan rasisme, seksisme, etnosentrisisme, diskriminasi dan prasangka etnis; respek pada perbedaan individu; menghargai keberagaman sebagai kekayaan budaya (Michaelis, 1980: 201-203). Di samping untuk meningkatkan pencapaian akademik, tujuan pendidikan multikultural juga untuk membantu siswa mengembangkan sikap yang lebih positif dan toleran terhadap perbedaan budaya, etnis, ras, dan kelompok agama; membantu siswa dari kelompok "teraniaya" untuk mengembangkan rasa percaya diri terhadap kemampuannya; mempengaruhi lembagalembaga masyarakat (White, 2003).

Untuk itu, guru perlu memahami secara mendalam dan jelas bentuk-bentuk bias seperti invisibilitas, stereotipe, selektivitas dan ketidakseimbangan, dan fragmentasi dan isolasi. Invisibilitas berarti bahwa mikrokultur tertentu, termasuk kelopok-kelompok tidak mampu, tidak terepresentasi secara material. Mereka dianggap kurang bernilai, kurang penting, dan kurang bermakna dalam masyarakat. Stereotipe menempatkan peran tradisional secara kaku pada suatu kelompok. Stereotipe terjadi secara lintas kultural dan kelompok-kelompok tertentu. Selektivitas dan ketidakseimbangan terjadi bila isu-isu dan situasi diinterpretasikan hanya dari satu perspektif, biasanya dari perspektif kelompok mayoritas. Fragmentasi dan isolasi terjadi bila diskusi tentang sesuatu seperti isu-isu, sumbangan, dan informasi tetang variasi kelompok ditempatkan dalam suatu sesi yang terpisah atau bab tertentu dalam suatu teks. Sementara itu, konsep-konsep yang perlu dipahami siswa adalah rasisme, sexisme, prasangka, diskriminasi, penindasan, ketidakberdayaan, ketidaksamaan kekuatan, persamaan, dan cap-cap negatif (Gollnick \& Chinn, 1991).

Dalam konteks Indonesia, karena situasi multikultural masih belum mencolok (satu sekolah masih dominan berisi murid-murid dari etnis yang sama) sabagaimana di negera-negara lain seperti Australia (negara yang paling multietnis di dunia,http://students.idp.com) dan Amerika Serikat (diperkirakan pada tahun 2050, 50\% rakyat Amerika adalah multikultur, Rosado,1996), maka ide multikultural itu dapat dimasukkan ke dalam kurikulum yang ada (Kurnas) secara inklusif.

Sesungguhnya, di antara berbagai keanekaragaman bangsa dan budaya masih lebih banyak persamaannya daripada perbedaannya. Ketika perbedaan yang sedikit itu dieksploitasi maka persamaan yang lebih banyak akan terlihat sebagai hal yang tidak berarti. Akan tetapi, jika persamaan yang dikemukakan, maka perbedaan yang sedikit akan tampak sebagai sekadar variasi yang justru menjadikannya serasi/indah. Oleh sebab itu, pendidikan multikultural diharapkan dapat meningkatkan kemampuan untuk 
melihat persamaan dan suatu situasi dari berbagai perspektif; memperoleh suatu peningkatan simpati terhadap perasaan orang lain ketika seseorang keluar dari budaya dominan mereka.

Penting disadari cara orang lain memahami sesuatu. Ketika kita menjadi “orang dalam" akan berbeda memandang budaya dengan ketika kita menjadi "orang luar". Sebagai "orang dalam" kita hanya dapat memahami budaya secara subjektif dan sebagai "orang luar" dapat memahaminya dengan objektif (Atmazaki \& Harbon, 1999). Pendidikan multikultural perlu menyediakan kedua pengalaman itu kepada murid-murid. Untuk dapat melaksanakan pendidikan multikultural dengan baik, maka (calon) guru juga harus dipersiapkan dengan pengalaman-pengalaman tersebut. Kurikulum pendidikan guru perlu disisipi dengan perspektif multikulturalisme sehingga mereka mampu mengembangkan pengalaman multikultural itu kepada murid-muridnya.

\section{Sastra Warna Lokal dalam Pendidikan Multikltural Berpspektif Jender}

Karya sastra, terutama yang warna lokal, merupakan materi ajar yang sangat cocok untuk pendidikan multikultural. Dengan karya sastra, siswa dapat memahami keberagaman budaya dan keunikan suatu etnis: masalah jender, ras, kelas sosial, orientasi seksual, dan lain-lain. Mempelajari novel yang berlatar belakang budaya tertentu, misalnya, dapat mengembangkan pemahaman siswa terhadap keberagaman perspektif pandangan dunia suatu etnis yang menghasilkan cerita tersebut (Saldana, 1995: xii). Sastra warna lokal mengungkapkan banyak hal tentang warisan, tradisi, nilai, dan simbol kelompok etnis dan hubungan antaretnis. Penggunaan drama berlatar belakang etnis tertentu, misalnya, tidak dimaksudkan untuk meningkatkan keterampilan siswa tentang laku (acting), tetapi untuk memberikan pemahaman kepada siswa tentang dunia multietnis tempat mereka hidup.

Dalam konteks inilah perspektif jender juga dapat ditempatkan. Melalui novelnovel yang mencitrakan berbagai peran perempuan dan laki-laki dalam masyarakat, siswa diajak untuk memahami bagaimana masing-masing masyarakat memandang lawan jenisnya berdasarkan budaya dan konstruksi sosialnya. Bagaimana menumbuhkan sikap simpati, dan tidak berprasangka negatif, atau toleran terhadap ketersiksaan Sitti Nurbaya dalam upayanya untuk mencintai Samsulbahri (Sitti Nurbayai), kepasrahan/keluguan Pariyem menerima perlakuan majikan mudanya (Pengakuan Pariyem), kesediaan (keterpaksaan) Srintil dalam "menjual" tubuhnya (Ronggeng Dukuh Paruk), ambisi Kenanga untuk meningkatkan kecerdasan perempuan Bali (Kenanga), untuk sekadar contoh. Bagi pembaca yang tidak memunyai pemahaman multikultural, tindakan-tindakan tokoh-tokoh cerita itu dapat menimbulkan prasangka negatif sehingga menimbulkan kebencian-kebencian dan dapat pula memberikan cap-cap tertentu terhadap suku yang melatarbelakangi cerita itu.

Tentu guru perlu menyadari bahwa di balik berbagai pandangan itu (yang mungkin plus-minus), harus ada ide atau tujuan yang jelas bahwa pada akhirnya, kepada siswa ditanamkan adanya keseimbangan peran antara perempuan dan laki-laki. Siswa diajak untuk "melawan" praktek-praktek ketidaksiembangan jender yang 
terefleksi di dalam sastra dengan menggunakan dalil-dalil, baik yang dibawa agama, budaya, maupun paham feminisme. Siswa perlu diajak untuk mengembangkan sikap toleransi sebagaimana ditunjuukkan oleh tokoh-tokoh dalam karya sastra.

\section{Simpulan}

Keberagaman etnis dengan karakteristiknya masing-masing potensial membawa konflik. Agar anak bangsa dapat lebih melihat persamaan daripada perbedaan maka pendidikan multikultural merupakan suatu kebutuhan yang mulai mendesak bagi bangsa yang majemuk seperti Indonesia. Sastra warna lokal merupakan bahan ajar yang sangat tepat untuk memberikan pemahaman multikulturalisme kepada siswa. Dengan menggunakan sastra warna lokal, guru dapat mengajak siswanya untuk memahami dan mengembangkan sikap toleransi, antiseksisme, membuang prasangka-prasangka negatif terhadap perempuan (ketidakseimbangan jender). Oleh sebab itu, sastra warna lokal perlu dipertimbangkan untuk dimasukkan sebagai bahan ajar secara inklusif dalam kurikulum pendidikan di Indonesia.

\section{Daftar Pustaka}

Abrams, M.H. (1971) A glossary of literary terms, New York: Holt, Rinehart, Inc.

Atmazaki \& Harbon, L. (1999) Interpreting culture: pre-service teachers taking control and making meaning across cultures," LSC Internet Journal, 1999, Issue 5, 2003.

http://www.educ.utas.edu.au/users/tle/JOURNAL/Articles/Atmazaki/Atmazaki. $\underline{\text { html. }}$.

Feinberg, W. (1996) The goals of multicultural education: a critical re-evaluation. http://www.ed.uiuc.edu/EPS/PES-yearbook/96_docs/feinberg.html

Garrett, S. (1992) Gender. London: Routledge.

Gollnick, D. M.,Chinn, P. C. (1991). Multicultural education for exceptional children. http://www.ericfacility.net/ericdigests/ed333620.html

Michaelis, J. U. (1980) Social studies for children, a guide to basic instruction. New jersey: Prentice Hall, Inc.

Navis, A.A. (1999) Warna lokal minangkabau dalam sastra indonesia, dalam Yang Berjalan Sepanjang Jalan, ed. A.A. Navis, Jakarta: Grasindo, 1999.

Rosado, C. (1996). What Makes a School Multicultural? http://www.edchange.org/multicultural/papers/caleb/multicultural.html

Rose, K. L. (2003) Gender Stereotypes and Sexual Archetypes. http://www.friesian.com/gender.htm 
Saldana, Johnny. Drama of Color, Improvisation with Multiethnic Folklore, (Portsmouth: Heinemann, 1995)

White, Hazel L. "Implementing the multicultural education perspective into the nursing education curriculum," Journal of Instructional Psychology, Dec, 2003. http://www.findarticles.com/p/articles/mi_m0FCG/is_4_30/ai_112686168

Wilson, Keith. "Multicultural Education", (2004),

http://www.edchange.org/multicultural/papers/keith.html

\section{Atmazaki}

Dosen Jurusan Bahasa dan Sastra Indonesia, Universitas Negeri Padang 